\title{
The Implementation Model of Premium Tariff to Accelerate the Use of Photovoltaic (PV) Rooftop in Jakarta
}

\author{
Muhammad Rezansyah Tangguh Prasetya, Rinaldy Dalimi* \\ Energy System Engineering, Universitas Indonesia
}

*Corresponding author:

E-mail:

rndalimi@gmail.com

\begin{abstract}
The renewable energy mix achievement in 2019 was 10,2 GW still under the national target which is $13,9 \mathrm{GW}$, where PV Rooftop only contributed for $0,19 \%(19,57 \mathrm{MW})$. In order to accelerate the use of PV Rooftop, a Premium Tariff of PV Rooftop need to be implemented by PT. PLN. To set the Premium Tariff research needed to be conducted to obtain the total of Premium Tariff and its implementation. In the implementation, customers will have the PV Rooftop with installment payments, however the excess energy that produced by PV Rooftop stated in Kilowatt Hour (Kwh) does not count as a reduction in the electricity bills until the end of the contract duration. In this research used quantitative and qualitative methods. Quantitative method, a calculation conducted to obtain the Premium Tariff that can be offered to customers. Whereas the qualitative is conducted a survey to see the customer interest on PV Rooftop and the selection of the Premium Tariff offer. In the research results showed 77\% customers of R2 (PLN Rate) in Jakarta are interested to use PV Rooftop however constrained by high initial investment. Therefore, installment payment scheme is offered with contract duration of 13 years for the capacity power $3.500 \mathrm{VA}, 8$ years for $5.500 \mathrm{VA}$ with the Rates ranging from IDR $1.444 / \mathrm{Kwh}$ to IDR $3.232 / \mathrm{Kwh}$. With the assumption that $77 \%$ customers of R2 Rate in Jakarta used Premium Tariff, it can increase the usage capacity of PV Rooftop by $220-800$ MW.
\end{abstract}

Keywords: Energy mix, photovoltaic rooftop, premium tariff

\section{Introduction}

In the last 5 years, the development of renewable energy has increased starting from 2008 the annual increase about $1 \mathrm{GW}$ which dominated with water energy, then followed with geothermal and biomass. Whereas for the use of solar energy namely Solar Power Plant and Photovoltaic (PV) Rooftop have developed too but the increase of the usage is not too large. However, it began to increase quite drastically since 2018 (Usman, 2020). This can be seen on table 1 and 2.

Table 1. Energy Mix 2014-2019

\begin{tabular}{lllllll}
\hline $\begin{array}{l}\text { Generator } \\
\text { Type (MW) }\end{array}$ & $\mathbf{2 0 1 4}$ & $\mathbf{2 0 1 5}$ & $\mathbf{2 0 1 6}$ & $\mathbf{2 0 1 7}$ & $\mathbf{2 0 1 8}$ & $\mathbf{2 0 1 9}$ \\
\hline PLTA & 5048,59 & 5068,59 & 5343,59 & 5343,59 & 5399,59 & 5558,52 \\
PLTB & 1,46 & 1,46 & 1,46 & 1,46 & 143,51 & 154,31 \\
PLTBg & 28,8 & 54,72 & 100,62 & 100,62 & 108,62 & 110,62 \\
PLTBm & 1359,87 & 1671,29 & 1740,54 & 1740,54 & 1758,54 & 1758,54 \\
PLTBn & 0 & 0 & 0 & 0 & 0 & 5 \\
PLTM & 111,26 & 148,71 & 211,4 & 240,55 & 267,79 & 311,14 \\
PLTMH & 76,95 & 90,15 & 95,87 & 103,76 & 104,76 & 106,36 \\
PLTP & 1403,3 & 1438,3 & 1533,3 & 1808,76 & 1948,3 & 2130,7 \\
\multicolumn{7}{r}{ To be continued } \\
\hline
\end{tabular}

How to cite:

Prasetya, M. R. T., \& Dalimi, R (2021). the implementation model of premium tariff to accelerate the use of photovoltaic (PV) rooftop in Jakarta. International Conference of Social Research with Multidisiplinary Approach (ICSRMA) 2021. NST Proceedings. pages 25-36. doi: $10.11594 /$ nstp.2021.1203 


\begin{tabular}{|c|c|c|c|c|c|c|}
\hline PLTS & 22,74 & 33,36 & 43,12 & 50,9 & 60,19 & 126,24 \\
\hline PLTS Atap & 0 & 0 & 0 & 0 & 0 & 19,57 \\
\hline $\begin{array}{l}\text { PLTS Hy- } \\
\text { brid }\end{array}$ & 0 & 3,5 & 3,5 & 3,5 & 3,5 & 3,5 \\
\hline $\begin{array}{l}\text { PLTS Hy- } \\
\text { brid (Sun- } \\
\text { W) }\end{array}$ & 0,08 & 0,08 & 0,08 & 0,08 & 0,08 & 0,08 \\
\hline PLTSa & 14 & 15,65 & 15,65 & 15,65 & 15,65 & 15,65 \\
\hline $\begin{array}{l}\text { TOTAL } \\
\text { (MW) }\end{array}$ & $8.067,05$ & $8.525,81$ & $9.015,42$ & $9.408,95$ & $9.810,53$ & $10.300,23$ \\
\hline
\end{tabular}

Source: Dewan Energi Nasional

Table 2. Target of energy mix n 2015-2020

\begin{tabular}{|c|c|c|c|c|c|c|c|c|c|c|}
\hline Energy & 2015 & 2016 & 2017 & 2018 & 2019 & 2020 & 2025 & 2030 & 2040 & 2050 \\
\hline Geothermal & $1.438,5$ & $1.653,5$ & $1.908,5$ & $2.493,5$ & $2.493,5$ & $3.109,5$ & $7.241,5$ & $9.300,0$ & $\begin{array}{l}\text { 13.423, } \\
0\end{array}$ & $\begin{array}{l}\text { 17.646, } \\
0\end{array}$ \\
\hline Water & $4.826,7$ & $4.871,7$ & $4.928,7$ & $5.103,7$ & $5.468,2$ & $5.615,2$ & $\begin{array}{l}\text { 17.986, } \\
7\end{array}$ & $\begin{array}{l}21.989, \\
4\end{array}$ & $\begin{array}{l}29.994, \\
7\end{array}$ & $\begin{array}{l}38.000, \\
0\end{array}$ \\
\hline $\begin{array}{l}\text { Minihydro \& } \\
\text { Micro hydro }\end{array}$ & 197,4 & 230,5 & 313,7 & 520,0 & 750,0 & $1.000,0$ & $3.000,0$ & $3.800,0$ & $5.400,0$ & $7.000,0$ \\
\hline Bioenergy & $1.671,0$ & $1.801,6$ & $1.381,0$ & $2.030,0$ & $2.200,0$ & $2.500,0$ & $5.500,0$ & $9.600,0$ & $\begin{array}{l}17.800, \\
0\end{array}$ & $\begin{array}{l}26.000, \\
0\end{array}$ \\
\hline Sun & 78,5 & 107,8 & 224,5 & 375,0 & 550,0 & 900,0 & $6.500,0$ & $\begin{array}{l}14,200, \\
0\end{array}$ & $\begin{array}{l}29.600, \\
0\end{array}$ & $\begin{array}{l}45.000, \\
0\end{array}$ \\
\hline Wind & 3,1 & 3,9 & 73,9 & 203,9 & 398,9 & 600,0 & $1.800,0$ & $7.040,0$ & $\begin{array}{l}17.520, \\
0\end{array}$ & $\begin{array}{l}28.000, \\
0\end{array}$ \\
\hline Each other & 372,0 & 809,8 & $1.232,6$ & $1.675,4$ & $2.059,2$ & $2.433,0$ & $3.125,0$ & $3.722,4$ & $4.911,2$ & $6.100,0$ \\
\hline Total & $8.587,2$ & $9.478,8$ & $\begin{array}{l}10.562, \\
9\end{array}$ & $\begin{array}{l}12.041, \\
5\end{array}$ & $\begin{array}{l}13.919, \\
8\end{array}$ & $\begin{array}{l}\text { 16.157, } \\
7\end{array}$ & $\begin{array}{l}45.153, \\
2\end{array}$ & $\begin{array}{l}69,651, \\
8\end{array}$ & $\begin{array}{l}118.64 \\
8,9\end{array}$ & $\begin{array}{l}167.64 \\
6,0\end{array}$ \\
\hline
\end{tabular}

Source: RUEN

It is seen in the figure that the development of PV Rooftop in 2019 still not optimal its only 19,57 MW or $0,19 \%$ of the total of Renewable Energy with 10,3 GW, which should be maximized considering Indonesia is a tropical country which has 6 months of summer in a year (Presiden Republik Indonesia, 2017).

In the different information explained that the total capacity of the usage of PV Rooftop by customers of PLN Jakarta reached one third of the total capacity of the usage of PV Rooftop all over Indonesia, this indicates that the potential of the customer growth of PV Rooftop in Jakarta is very high. This is proven by the trend of customer growth of PLN which used PV Rooftop in the last 2 years from January 2019 until February 2021 increased by $47 \%$ or 316 Customers. From the total increase of 316 customers, R2 Tariff (divided into 3500VA, 4400VA and 5500VA) reach the highest increase with $66 \%$ (Figure 1). 


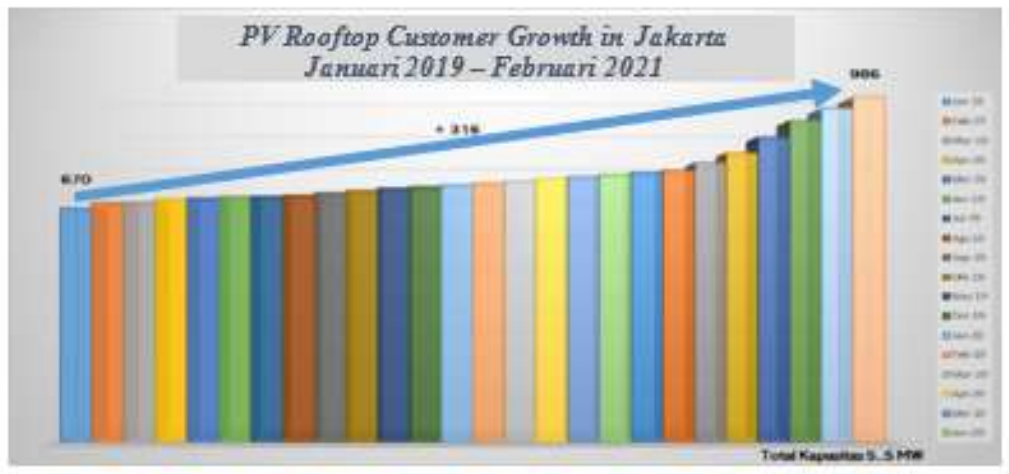

Figure 1. Customer growth with PV rooftop in Jakarta (Source: PT.PLN)

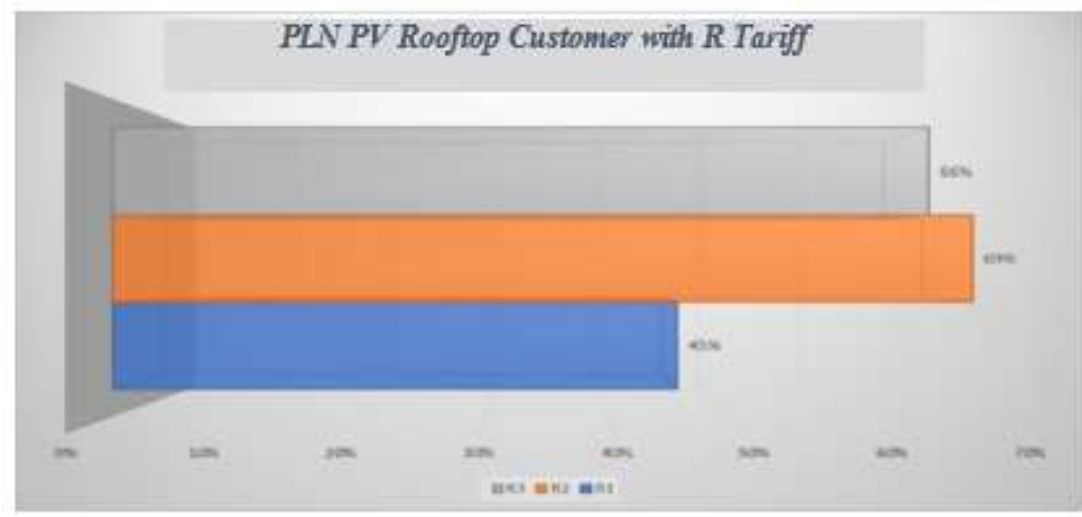

Figure 2. PV rooftop costumers in Jakartaa (Source: PT. PLN)

\section{Material and Methods Step research}

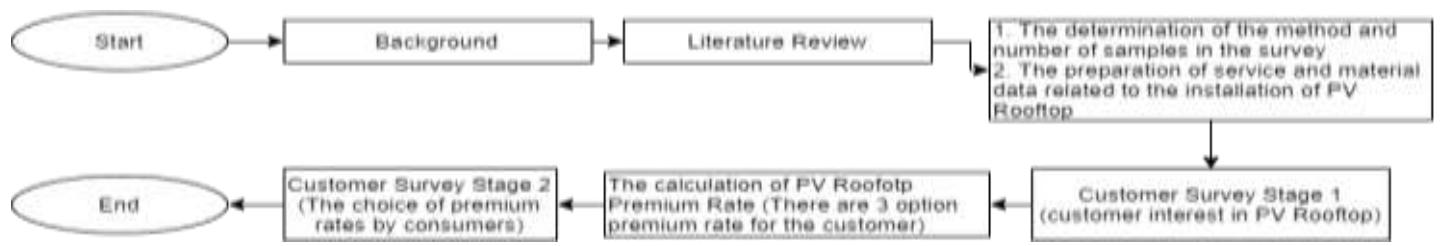

Figure 3. Steps research

The research is preceded by the problem formulation, purpose and problem limitation, then the hypothesis is set to complete for the first step, these are assembled in background. Moreover, it is continued by literature review to obtain references in determining the appropriate method and research steps. The research begins by conducting a survey to customers of PT. PLN located in Bintaro (South Tangerang) with the total of 384 respondents of R2 Electricity Tariff. The Survey is aimed to determine the interest of PT. PLN customers on PV Rooftop and to determine what the obstacles of the customers to use PV Rooftop. The results of the first stage survey will become the references in the calculation of Premium Tariff that produced 3 schemes of Premium Tariff. Lastly, the calculation results of Premium Tariff is became the main material for the second stage of survey. 


\section{Qualitative method}

The methods used in this research are Qualitative and Quantitative. The definition of qualitative method is a research procedure which produced descriptive data in the form of written or spoken words from the people and the observed behavior (Basrowi \& Suwandi, 2008). The qualitative research related to ideas, perceptions, opinions, or trust of the observed people all of which cannot be measured by numbers (Basuki, 2010). In this research, observation is used on customers of PT. PLN (Persero) with R2 Rate in Jakarta regarding PV Rooftop, either interest or availability of using the offered Premium Tariff. The steps conducted in this research are as follows:

\section{Qualitative method}

\section{Determination of survey location}

In the research a location is needed for the samples collection on customer respondents of PT. PLN Jakarta with R2 Tariff. The sampling techniques are divided into two types namely random (random sampling, probability sampling method) and non-random (non-random sampling, nonprobability sampling). ${ }^{7}$ In this research the Probability Sampling Technique is used which defined as a data or sample collection technique so that all data have the same probability of being selected as a sample. Thus, there is no obstacle in conducting the research on the possibility or probability of any element if then selected as a sample (Kuncoro, 2009). The next step is determining the method type of the Probability Sampling which consist of Simple Random Sampling, Proportionate Stratified Random Sampling, Disproportionate Stratified Random Sampling, Area (Cluster) Sampling. ${ }^{8}$ Then, in this research is selected by using Area (Cluster) Sampling Technique in conducting the survey in the research. This is based on the observed object or a lot of data, in this case the observed object is customers of PT. PLN whose scope is very large and wide.

Area sampling technique is conducted through two steps (Sugiyono, 2015). The first step is determining the area sample. In this research the sampling area determined is PT. PLN Jakarta area which divided into 15 work areas namely Bandengan, Bintaro, Bulungan, Ciputat, Jatinegara, Kramat Jati, Cengkareng, Tanjung Priok, Marunda, Ciracas, Pondok Gede, Pondok Kopi, Menteng, Kebon Jeruk and Cempaka Putih. Form these 15 work areas of PLN Jakarta, Bintaro is selected as the survey target. This is because the customers of R (Consist of R1, R2, and R3) Tariff are most in Bintaro. Then the R2 Tariff is determined (500VA, 4.400VA and 5.500VA) which have never installed a PV Rooftop at home. The second step is determining the people in the area by sampling. After this step is conducted, the next step is determining the total of respondents which can represent the population.

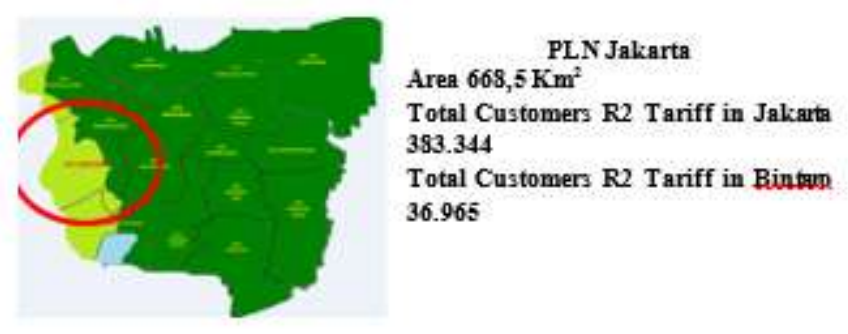

Figure 4. Survey maps

\section{Determination of total respondents}

After the target location for the observation is determined, the next step is to determine the total of respondents to represent the population. In this research the formula by Stephen Isaac and Willian B Michael is used through the equation as follows (Basrowi \& Suwandi, 2008): 


$$
S=\frac{\lambda^{2} \times N \times P \times Q}{d^{2}(N-1)+\lambda^{2} \times P \times Q}
$$

Where :

$$
\begin{aligned}
& S=\text { Total Sample } \\
& N=\text { Total Population } \\
& \lambda 2=\text { Chi Square, with } \mathrm{df}=1 \text {, error rate } 1 \%, 5 \% \text { and } 10 \% \\
& \mathrm{~d}=\text { The difference between expected sample and the difference that occurs, for example } 1 \%, 5 \% \text { and } 10 \% \\
& P=Q=0,5 \\
& \text { Chi square } 5 \% \text { or } 3,841
\end{aligned}
$$

With the total customers of PT.PLN Jakarta with R2 Tariff is 383.344, therefore by using the formula below the total respondents obtained which represent the population is as follows. Chi square $5 \%$ or 3,841

$$
s=\frac{3,841 \times 383.344 \times 0,5 \times 0,5}{0,05^{2} \times(383.344-1)+3,841 \times 0,5 \times 0,5}=383,76=384 \text { Responden }
$$

\section{Questionnaire questions}

\begin{tabular}{|c|c|}
\hline Name & 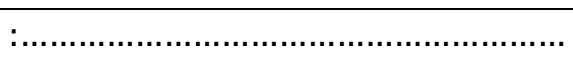 \\
\hline Costumers ID & : \\
\hline Educational Background & 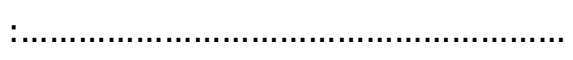 \\
\hline Work Field & : \\
\hline Salary & (2) \\
\hline Do you know information about PV rooftop & :Yes/ No \\
\hline The reason why did not install PV rooftop yet & : \\
\hline How big the willingness to install PV rooftop & : Choose Number 1 to 5 \\
\hline
\end{tabular}

The questionnaire for the respondents is conducted by using online form, was Google Form. The question types are divided into 2 parts. The first part aims to determine the interest of the

\begin{tabular}{|c|c|}
\hline The scheme you choose? & .. \\
\hline
\end{tabular}
usage of PV Rooftop moreover to determine the reasons why they have not used the PV Rooftop. The second part aims to determine 1 scheme of Premium Tariff which is appropriate to be implemented by PT. PLN (Persero). The following is the list of questions asked to the respondents, figure 6 is the first survey and figure 7 is the second survey.

Table 3. List of question part 1

Table 4. List of question part 2

\section{Quantitative method}

The quantitative method explained according to the name, many are required to use numbers, starting from the data collection, the interpretation of the data, and the display of the results (Arikunto, 2013). In the research will calculate the total of Premium Tariff in several schemes which then offered to the customers of PT. PLN (Persero). The purpose of making the Premium Tariff in several schemes is that it is expected for the respondents in this case is the customers of PT. PLN with R2 Tariff to have several options to choose the rate suitable with the customer's economic capability. 


\section{Calculation of financial eligibility of premium tariff}

To calculate the financial eligibility, Microsoft Excel is used to search the total of increase in the electricity rate (IDR) and in what year was the investment made by PT. PLN. The variables used in this calculation are as follows:

1. Determining the minimum of electricity used $=130$ Hours $/$ month for $3500 \mathrm{VA}$ and 150 Hours/Month for 4400VA and 5500VA.

2. Electricity Cost of Energy = Rp. 985/Kwh (MESDM, 2018)

3. $\quad$ R2 Electricity Base Rate $=$ Rp. 1.444,7/Kwh (cost of energy is included).

4. Discount Rate $=12 \%$.

5. Operating and Maintenance $(\mathrm{OM})$ of electrical equipment $=3 \%$ per year .

6. The price of PV Rooftop package with various inverter output 750 Watt until 5000 Watt.

In the point number 6 below is the Value of investment included in the calculation, the value is obtained from the average of PV prices by several Rooftop PV installer company in Jakarta. The cost includes the maintenance fee for the PV Rooftop set. The following is the PV Rooftop set cost list

Table. 5 Detail of investment each PV capacity

Total Investment

\begin{tabular}{cc}
\hline PV Capacity (Watt) & Total Invesment (Rp) \\
\hline 750 & Rp. 19.597 .190 \\
1000 & Rp.26.347.190 \\
1500 & Rp.36.578.315 \\
2000 & Rp.43.559.440 \\
3000 & Rp.61.397.690 \\
4000 & Rp.82.271.940 \\
5000 & Rp.96.186.190 \\
10000 & Rp.179.551.797 \\
20000 & Rp.345.331.797 \\
50000 & Rp.832.551.797 \\
\hline
\end{tabular}

Table 6. Assumption and formula

\begin{tabular}{|c|c|c|c|}
\hline Discount Rate & $12 \%$ & Cash Inflows & Formula \\
\hline Investment (Rp) & Based On Capacity & Rupiah per Kwh & $\begin{array}{l}\text { Total Tariff Kwh Per } \\
\text { Year }\end{array}$ \\
\hline Price R Tariff & Rp.1.445 & Cash Inflow & $\begin{array}{l}\text { Total Tariff Kwh Per } \\
\text { Year }\end{array}$ \\
\hline $\begin{array}{l}\text { Cost of Electricity } \\
\text { Production }\end{array}$ & Rp.985 & PV of Cash Inflow & $\begin{array}{l}\text { Cumulative Present } \\
\text { Value Inflow Each } \\
\text { Year }\end{array}$ \\
\hline $\begin{array}{l}\text { Minumum Duration } \\
\text { of Electricity Used }\end{array}$ & $\begin{array}{l}130 \text { Hour for } \\
3.500 \mathrm{VA}, 150 \text { Hour } \\
\text { for } 4.400 \text { and } 5.500 \\
\text { VA }\end{array}$ & Cash Outflow & Formula \\
\hline Contract Duration & Payback Period & Initial Invesment & $\begin{array}{l}\text { Cost Invesment of } \\
\text { PV Rooftop (Rp) }\end{array}$ \\
\hline
\end{tabular}

To be continued 


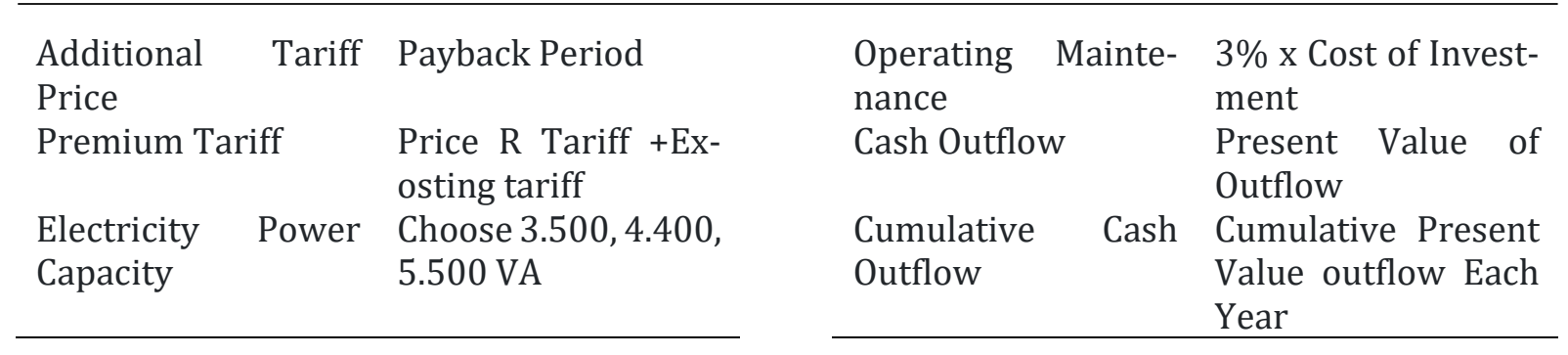

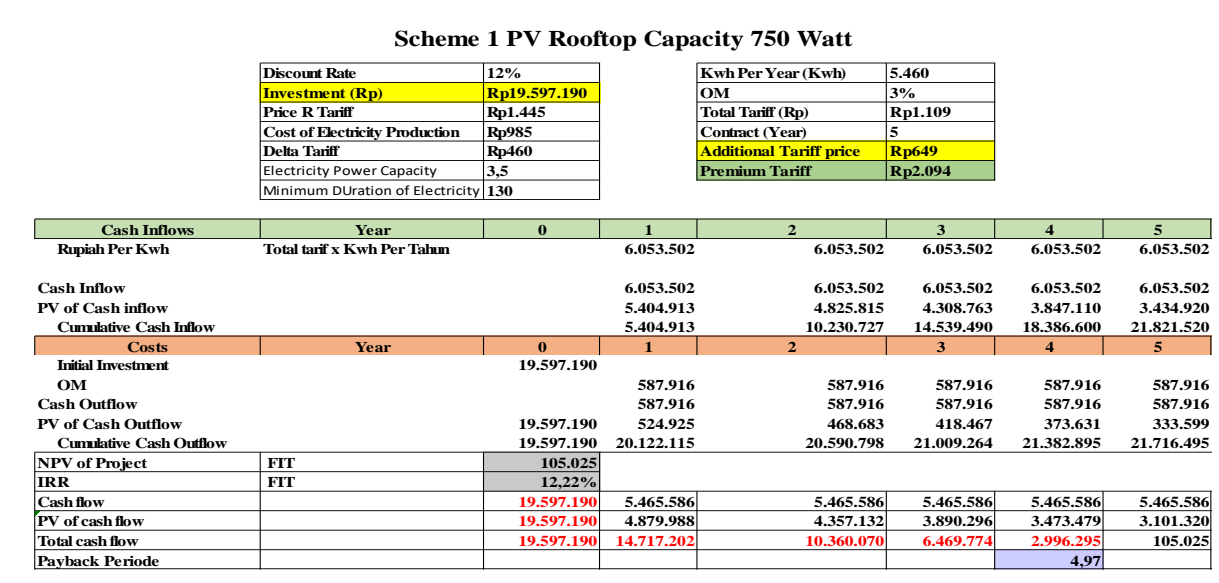

Figure 5. Scheme 1 PV rooftop capacity 750 W 3.500VA

The Premium Tariff calculation is used Microsoft Excel as the media in order to simplify the calculation. The calculation is divided into three segments with various capacity of PV Rooftop. This is because each PV Rooftop has different investment value, the higher the PV rooftop the higher the investment needed. There are three schemes resulting from the calculation, which differentiate the first second and third schemes is contract duration of the Premium Tariff contained in the Payback Period calculation, therefore this will affect the high and low of Premium Tariff. The shorter the Payback Period, the more expensive Premium Tariffs, and vice versa. The following is the example of the 3 calculation of 3 schemes with PV Rooftop capacity of 750 Watt for 3.500VA, 750 Watt for 4.400VA, and 1000 Watt for 5.500VA.

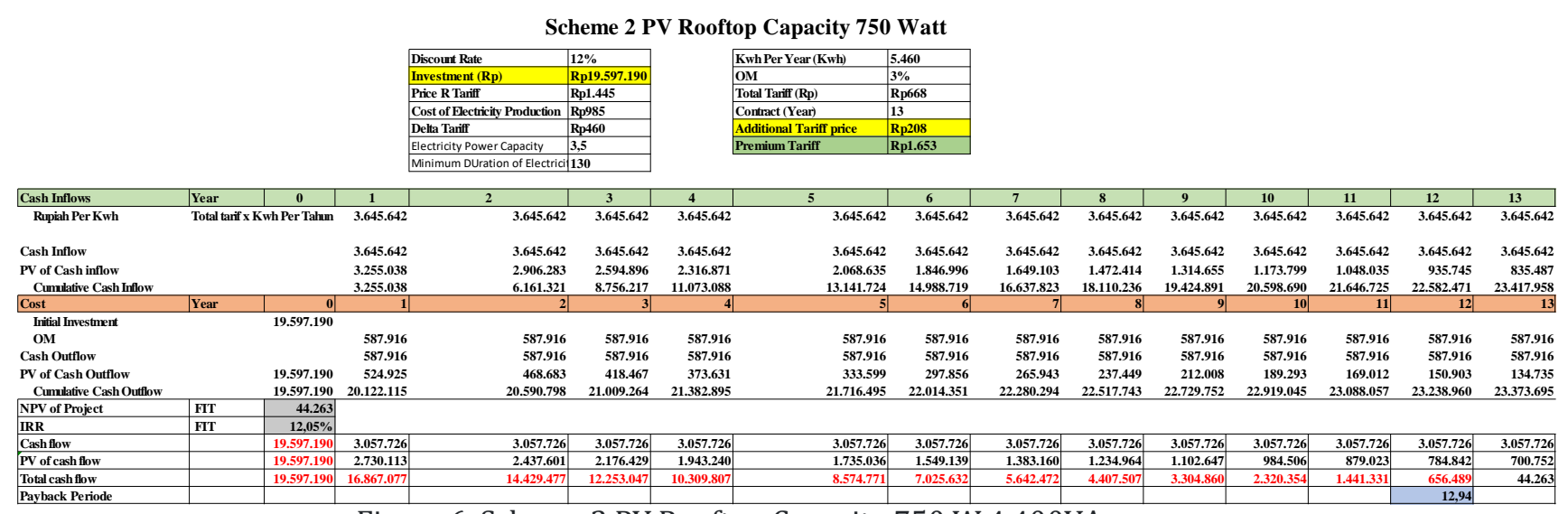

Figure 6. Scheme 2 PV Rooftop Capacity 750 W 4.400VA 


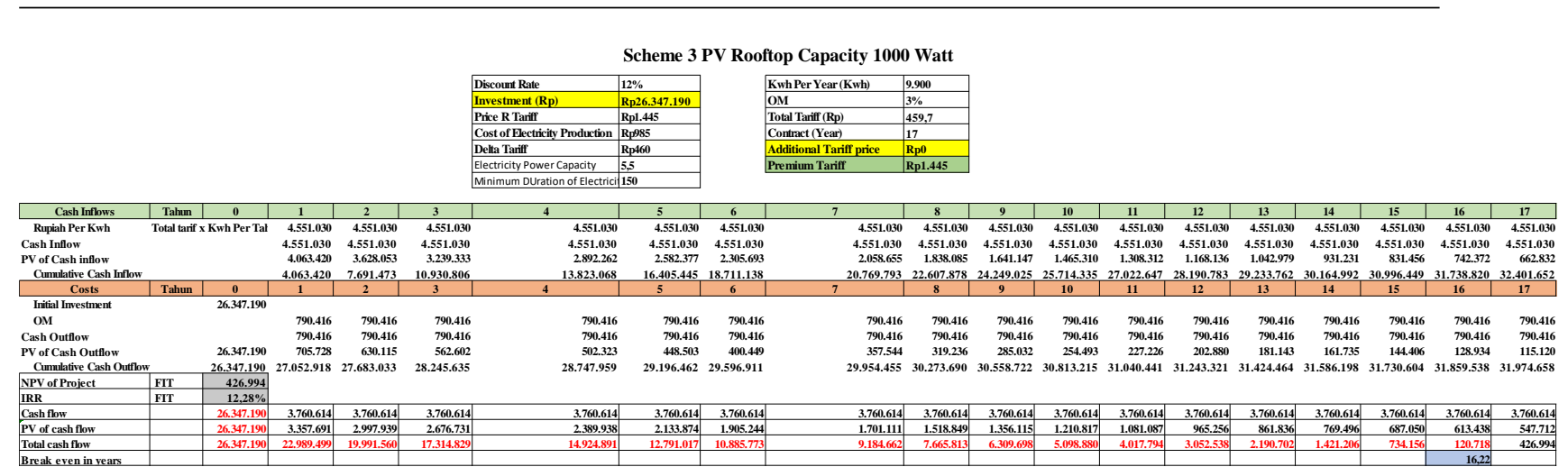

Figure 7. Scheme 3 PV Rooftop Capacity 1000 W 5.500VA

In an investment, an investment can be said eligible if the NPV $>0$, according to this research that the investment of PT. PLN in creating the Premium Tariff must see the NPV value in the calculation. To find NPV the formula used is as follows (Kasmir \& Jakfar, 2003).

$$
\mathrm{NPV}=\left\{\frac{\mathrm{P}}{(1+\mathrm{i}) \mathrm{t}}\right\}^{-\mathrm{C}}
$$

Where: $\quad \begin{array}{ll}\text { NPV } & =\text { Net Present Value } \\ \mathrm{P} & =\text { Cash inflow } \\ \mathrm{i} & =\text { Interest rate } \\ \mathrm{t} & =\text { Investment life cycle } \\ \mathrm{C} & =\text { Initial Investment }\end{array}$

In determining NPV, the steps needed to be done namely (Kuswandi, 2007).

1. Determining the interest rate (discount rate) which will be used, in this case we can use:

- The desired cost of capital or rate of return.

2. Calculating the present value from the cash flow with the discount rate.

3. Calculating the present value from the total of investments.

4. Calculating the NPV by using the formula in Equation 2.

Whereas to find the IRR value the formula used is as follows (Safrizal et al., 2018).

$$
I R R=i_{1}+\frac{N P V_{1}}{\left(N P V_{1}-N P V_{2}\right)}\left(i_{2}-i_{1}\right)
$$

Where: $\quad$ IRR $=$ Internal Rate of Return

$\mathrm{i} 1=$ The discount rate that produced NPV -

$\mathrm{i} 2=$ The discount rate that produced NPV +

NPV1 = Positive NPV

NPV2 $=$ Negative NPV

\section{Results and Discussion}

Based on the steps that have been taken, the research results are obtained which divided into 3 parts, those are:

\section{First stage survey results}

This first stage survey aims to obtain information regarding the interest of customers of PT. PLN represented by customers with R2 Tariff which have not used the PV Rooftop. Moreover, this first stage survey also aims to determine the constraints or obstacles behind the community for not using the PV Rooftop. From the survey results the results obtained are as follows: 


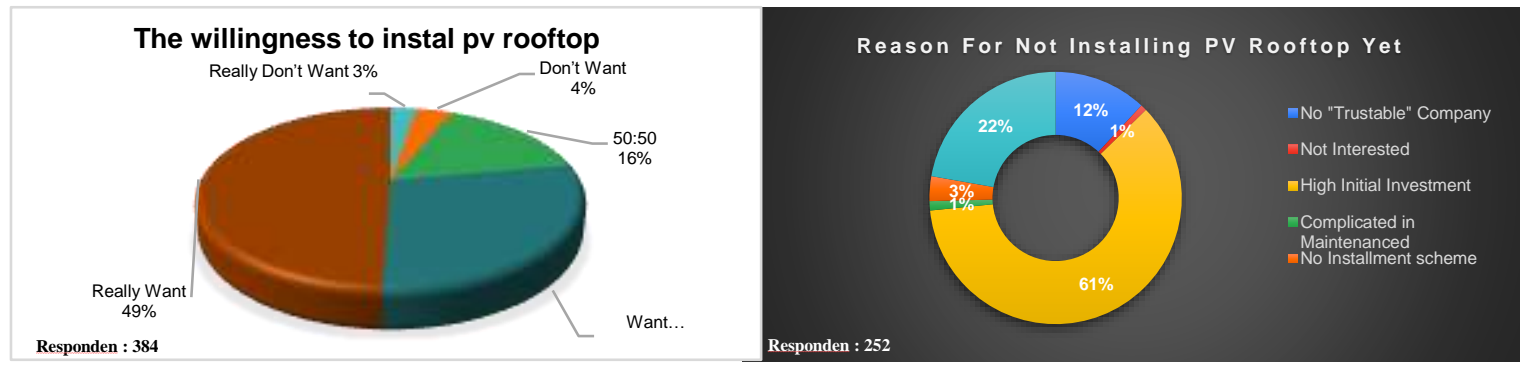

Figure 8. The willingness to install PV RT and reasons for not installing PV Rooftop Yet

The survey results showed that from 384 customers 77\% (252 Customers) are interested to have PV rooftop and only 7\% (27 Customers) who do not want, whereas the rest 16\% (105 Customers) are uncertain. From the $77 \%$ or 252 customers who wants to install PV in their home. From 77\% (252 Customers) who wants to install PV in their home however do not have the equipment yet, there are several obstacles faced in owning the PV Rooftop. Those are, a huge investment by $66 \%$, then followed by do not know about the process of maintenance and operation of PV Rooftop (22\%) and the third is there is no one company that can be trusted to handle the operation of PV Rooftop (12\%).

\section{The results of premium tariff scheme calculation}

From the 1st stage survey results revealed that the biggest reason why respondents still do not have the PV Rooftop is because of the huge initial investment by $66 \%$, this certainly can be solved by eliminating the initial investment costs and replaced it with installment payment. In the Calculation stage of this research aims to find the alternative of several schemes of PV Rooftop ownership without Down Payment but with installments within a certain contract period, which can also be called as the Premium Tariff scheme. The calculation produced 3 schemes of Premium Tariff with different rate cost and contract duration of each scheme, therefore respondents can choose according to the ability and desire.

Table 7. Calculation result of premium tariff offer scheme

\begin{tabular}{|c|c|c|c|c|c|c|c|}
\hline Scheme & $\begin{array}{l}\text { Capacity } \\
\text { Power } \\
\text { (VA) }\end{array}$ & $\begin{array}{l}\text { Duration } \\
\text { Electric- } \\
\text { ity Used } \\
\text { (Hour) }\end{array}$ & $\begin{array}{l}\text { PV Ca- } \\
\text { pacity }\end{array}$ & $\begin{array}{l}\text { Price } \mathrm{R} \\
\text { Tarlff Ex- } \\
\text { isting }\end{array}$ & $\begin{array}{l}\text { Addi- } \\
\text { tional to } \\
\text { Premium } \\
\text { Tariff }\end{array}$ & $\begin{array}{l}\text { Premium } \\
\text { Tariff }\end{array}$ & Contract \\
\hline & & & 750 & Rp 1.445 & Rp 649 & Rp 2.094 & 5 Years \\
\hline & & & 1000 & Rp 1.445 & Rp 1.030 & Rp 2.475 & \\
\hline & 3500 & 130 & 1500 & Rp 1.445 & Rp 1.610 & Rp 3.055 & \\
\hline & & & 2000 & Rp 1.445 & Rp 2.005 & Rp 3.450 & \\
\hline & & & 3000 & Rp 1.445 & Rp 3.010 & Rp 4.455 & \\
\hline & & & 750 & Rp 1.445 & Rp 304 & Rp 1.749 & \\
\hline & & & 1000 & Rp 1.445 & Rp 568 & Rp 2.013 & \\
\hline & 4400 & 150 & 1500 & Rp 1.445 & Rp 967 & Rp 2.412 & \\
\hline \multirow[t]{3}{*}{1} & & & 2000 & Rp 1.445 & Rp 1.238 & Rp 2.683 & \\
\hline & & & 3000 & Rp 1.445 & Rp 1.935 & Rp 3.380 & \\
\hline & & & 4000 & Rp 1.445 & Rp 2.746 & Rp 4.191 & \\
\hline
\end{tabular}




\begin{tabular}{|c|c|c|c|c|c|c|c|}
\hline & & & 750 & Rp 1.445 & Rp 151 & Rp 1.596 & \\
\hline & & & 1000 & Rp.1.445 & Rp 362 & Rp 1.807 & \\
\hline & & & 1500 & Rp.1.445 & Rp 681 & Rp 2.126 & \\
\hline & 5500 & 150 & 2000 & Rp.1.445 & Rp 899 & Rp 2.344 & \\
\hline & & & 3000 & Rp.1.445 & Rp 1.454 & Rp 2.899 & \\
\hline & & & 4000 & Rp.1.445 & Rp 2.105 & Rp 3.550 & \\
\hline & & & 5000 & Rp.1.445 & Rp 2.540 & Rp 3.985 & \\
\hline & & & 750 & Rp.1.445 & Rp 208 & Rp 1.653 & 13 years \\
\hline & 3500 & 130 & 1000 & Rp.1.445 & Rp 437 & Rp 1.882 & \\
\hline & & & 1500 & Rp.1.445 & Rp 785 & $\mathrm{Rp} 2.230$ & \\
\hline & & & 2000 & Rp.1.445 & Rp 1.025 & $\mathrm{Rp} 2.470$ & \\
\hline & & & 3000 & Rp.1.445 & Rp 1.630 & Rp 3.075 & \\
\hline & & & 750 & Rp.1.445 & Rp 0 & Rp 1.445 & \\
\hline & & & 1000 & Rp.1.445 & Rp 159 & Rp 1.604 & \\
\hline \multirow[t]{12}{*}{2} & 4400 & 150 & 1500 & Rp.1.445 & Rp 400 & Rp 1.845 & \\
\hline & & & 2000 & Rp.1.445 & Rp 563 & $\mathrm{Rp} 2.008$ & \\
\hline & & & 3000 & Rp.1.445 & Rp 980 & $\mathrm{Rp} 2.425$ & \\
\hline & & & 4000 & Rp.1.445 & Rp 1.470 & Rp 2.915 & \\
\hline & & & 750 & Rp.1.445 & $\mathrm{Rp} 0$ & Rp 1.445 & 8 years \\
\hline & & & 1000 & Rp.1.445 & Rp 160 & Rp 1.605 & \\
\hline & 5500 & 150 & 1500 & Rp.1.445 & Rp 399 & $\mathrm{Rp} 1.844$ & \\
\hline & & & 2000 & Rp.1.445 & Rp 568 & $\mathrm{Rp} 2.013$ & \\
\hline & & & 3000 & Rp.1.445 & Rp 995 & $\mathrm{Rp} 2440$ & \\
\hline & & & 4000 & Rp.1.445 & Rp 1.514 & Rp 2959 & \\
\hline & & & 5000 & Rp.1.445 & Rp 1.817 & Rp 3.262 & \\
\hline & & & 750 & NO & NO & NO & NO \\
\hline \multirow[t]{3}{*}{3} & 5500 & 150 & & AVAILA- & AVAILA- & AVAILA- & AVAILA- \\
\hline & & & & BLE & BLE & BLE & BLE \\
\hline & & & 1000 & Rp 1.445 & Rp 0 & Rp 1.445 & 17 \\
\hline
\end{tabular}

\section{Second stage survey result}

From the calculation produce 3 schemes of Premium Tariff. For the 3.500VA and 4.400VA there are 2 schemes, whereas for 5.500VA there are 3 schemes. All of these schemes were again asked to the respondents to determine, which of the Premium Tariff scheme suitable to be implemented massively later by PT. PLN (Persero). Just as the research initial step, survey is conducted by using google form, the following is the survey results which can be found in figure 12 for 3.500VA, figure 13 for $4.400 \mathrm{VA}$ and figure 14 for 5.500VA. 

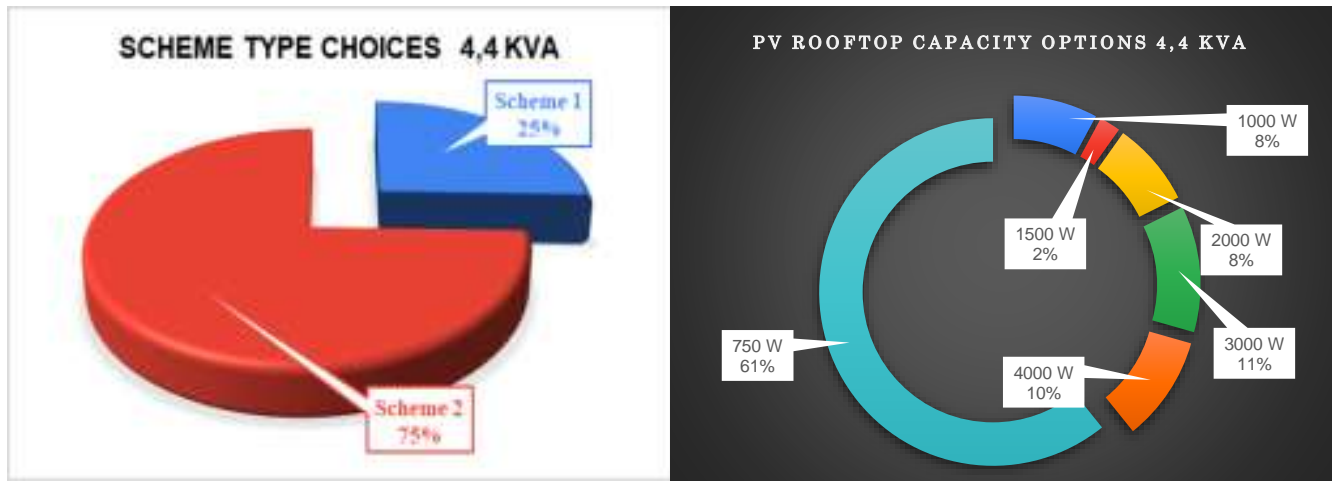

Figure 9. Scheme type choices and PV rooftop capacity option 4,4 KVA

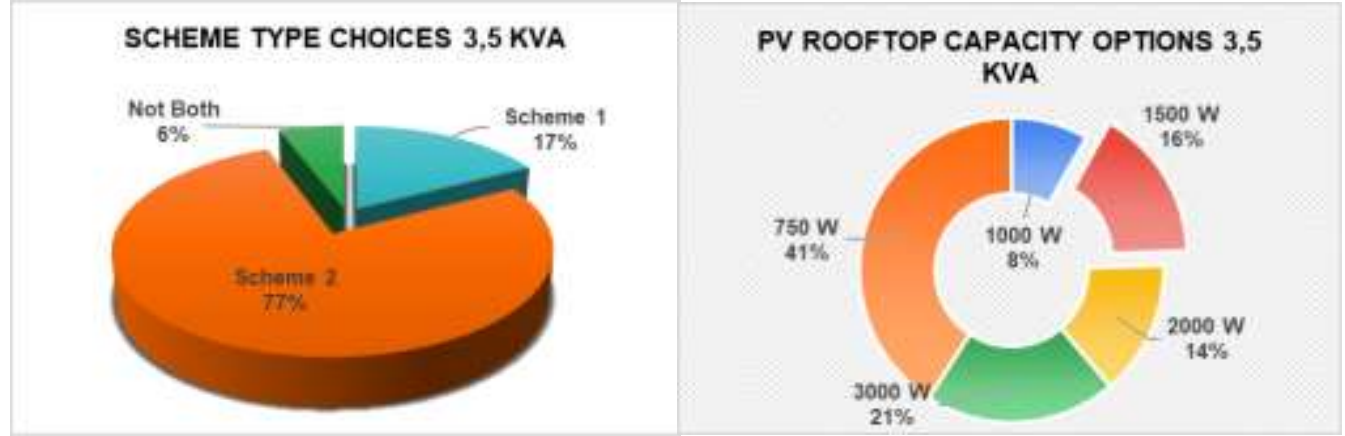

Figure 10. Scheme type choices and PV rooftop capacity option 3,5 KVA
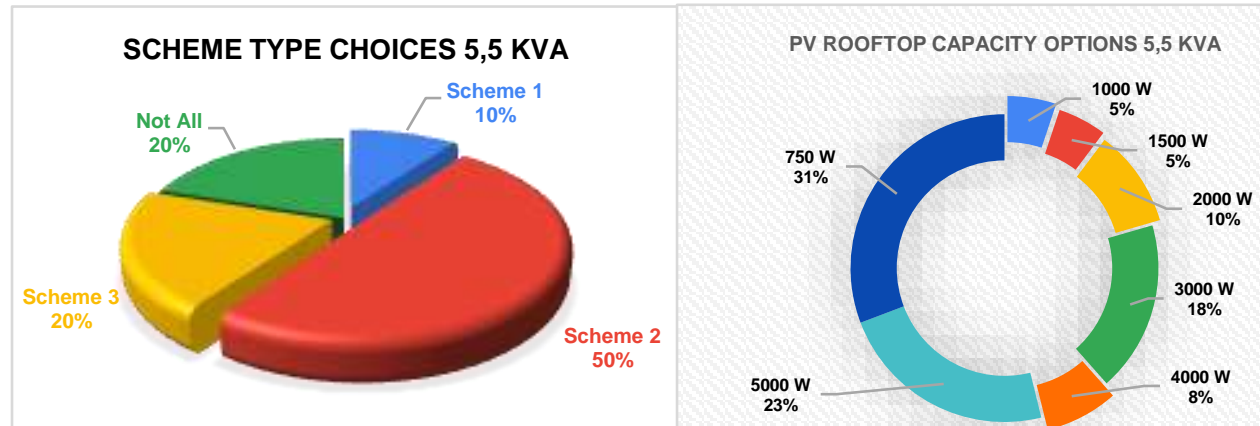

Figure 11. Scheme type choices and PV Rooftop Capacity Option 5,5 KVA

\section{Conclusion}

1. According to the conducted survey, there are $77 \%$ customers of $\mathrm{R} 2$ rate in Jakarta area which are interested to use PV Rooftop however still constrained by the huge initial investment.

2. There are several Premium Tariff schemes offered to the customers 3.500VA and 4.400VA and 5.500 VA.

3. All respondents which are interested to use PV Rooftop but still constrained by the huge initial investment, either for 3.500VA, 4.400VA and 5.500VA, 750W PV Rooftop capacity. 
4. Customers of power of 3.500 VA chose scheme 2 with contract duration of 13 years and the increase in Rp/Kwh rate starting from Rp. 208 to Rp. 1.630. Then for the customers of 4.400 VA chose scheme 2 with contract duration of 13 years and the increase in $\mathrm{Rp} / \mathrm{Kwh}$ starting from Rp. 0 to Rp. 1.470. Whereas for the customers of 5.500VA chose scheme 2 with contract duration of 8 years and the increase in Rp/Kwh starting from Rp. 0 to Rp. 1.787.

5. With the total customers R2 in Jakarta as of February 2021 there are 383.344 customers, therefore by using the assumption of the research results $77 \%$ of customers are interested to use Premium Tariff with the smallest power capacity of PV Rooftop which is 750W then will increase the capacity of the use of PV Rooftop by 220-800 MW.

\section{Acknowledgment}

I thank Professor Rinaldy Dalimi from the Faculty of Engineering University of Indonesia as the counsellor in this research, which have directed and became my role model especially while studying at the University of Indonesia. I also thank PT. PLN (Persero) for the availability to assist and provide the necessary data to complete the research. Moreover, for the anonymous reviewers for their valuable comments. I also thank all respondents, customers of PT. PLN (Persero) for their availability in answering each question given completely. It is expected that by this research the output in the form of Premium Tariff can be implemented by PT. PLN (Persero) and used as references and recommendationss for PT. PLN (Perser) in formulating policies, regulations and implementation of the Premium Tariff all over Indonesia in order to increase the use of Renewable Energy.

\section{References}

Arikunto, S. (2013). Prosedur penelitian: Suatu pendekatan praktik. Jakarta: Rineka Cipta.

Basrowi \& Suwandi. (2008). Memahami penelitian kualitatif. Jakarta: Rineka.

Basuki, S. (2010). Metode penelitian. Jakarta: Penaku.

Kasmir, \& Jakfar. (2003). Studi kelayakan bisnis. Jakarta: Predana Media Grup.

Kuncoro, Mudrajad. 2009. Metode riset untuk bisnis dan ekonomi. Edisi 3. Penerbit Erlangga.

Kuswandi. 2007. Analisis keekonomian proyek. Yogyakarta: Andi.

Menteri Energi dan Sumber Daya Mineral. (2018). Peraturan Menteri Energi dan Sumber Daya Mineral Nomor: 55 k/ 20 / MEM / 2019 Tentang Bssaran Pokok Penyediaan Pembangkitan PT Perusahaan Listrik Negara (Persero) Tahun 2018.

Pertumbuhan Pelanggan PLTS Atap di Jakarta [https://web.pln.co.id], diakses 7 May 2021.

Presiden Republik Indonesia. Peraturan Presiden Republik Indonesia Nomor: 22 Tahun 2017 Tentang Rencana Umum Energi Nasional.

Safrizal, A. M., Ibrahim, A., \& Irfan, M. (2018). Analisis kelayakan finansial usaha pebibitan lada di desa sukadana baru Kecamatan Marga Tiga Kabupaten Lampung Timur, JIIA, 6(2), 1-6.

Sugiyono. (2015). Metode penelitian pendidikan. 2nd Edition. Bandung:Alfa Beta

Usman, E. dkk. (2020) Bauran energi nasional. Jakarta: Dewan Energi Nasional (DEN). 